\title{
PKM PENINGKATAN KAPASITAS DESAWISATA DI DESA GALENGDOWO KECAMATAN WONOSALAM KABUPATEN JOMBANG
}

\author{
Sayekti Suindyah Dwiningwarni ${ }^{1}$, Mei Indrawati ${ }^{2}$, Machrus Ali ${ }^{3}$, Syamsiyah Yuli Dwi Andari ${ }^{4}$ \\ ${ }^{12}$ Universitas Wijaya Putra Surabaya \\ ${ }^{3}$ Universitas Darul 'Ulum Jombang \\ ${ }^{4}$ Universitas Muhammadiyah Yogyakarta
}

Email:sayektisuindyah@uwp.ac.id, email: meiindrawati@uwp.ac.id, email:machrus7@gmail.co, email: syamsiyahyuli@gmail.com

\begin{abstract}
Abstrak
Desa Galengdowo Kecamatan Wonosalam Kabupaten Jombang yang memiliki potensi wisata wisata yang baik, tetapi masih belum dikelola secara maksimal. Mitra program kemitraan ini adalah Pokdarwis Argo Wayang yang merupakan salah satu unit usaha BUMDESA Lohjinawi Desa Galengdowo. Selama masa pandemi covid-19, dan diberlakukannya peraturan tentang PSBB, PPKM Darurat dan PPKM Level 1-4, menyebabkan obyek wisata di desa ini ditutup total. Penutupan obyek wisata ini memberikan dampak terhadap penurunan jumlah kunjungan wisatawan ke lokasi wisata bahkan sampai titik nol (tidak ada pengunjung), sehingga tidak menghasilkan pendapatan baik bagi desa atau pun masyarakat.

Tujuan program ini adalah pertama, meningkatkan kapasitas desawisata di masa pandemi covid-19, kedua, meningkatkan promosi desawisata melalui website, ketiga, meningkatkan managerial dan ketrampilan pengurus dan anggota Pokdarwis dan Bumdes di bidang kepariwisataan, dan keempat, menyediakan kelengkapan desa wisata. Metode yang digunakan adalah, pertama, membuat atau merancang website dan database, kedua, pelatihan dan pendampingan pengoperasian website dan database, ketiga, pelatihan manajemen pariwisata dan pemandu wisata. Hasil program kemitraan ini antara lain, pertama, optimalisasi promosi obyek wisata dengan dibuatkannya domain galengdowo.id, kedua, optimlisasi pengelolaan desa wisata oleh Pokdarwis melalui website galengdowo.id, ketiga, meningkatnya manajerial dan ketrampilan pengurus dan anggota Pokdarwis dan Bumdes di bidang kepariwisataan, dan keempat, tersedianya sarana pendukung untuk promosi desawisata berupa penunjuk arah ke lokasi wisata.
\end{abstract}

Kata Kunci : Desawisata, Inovasi Sosial, Inovasi Teknologi, Inovasi Manajemen

\section{PENDAHULUAN}

Kegiatan wisata merupakan salah satu kegiatan yang sangat digemari oleh masyarakat pada akhir abad 19, khususnya di Indonesia. Pada abad tersebut masyarakat Indonesia tidak lagi beripikir bahwa waktu yang mereka miliki hanya dihabiskan untuk bekerja dan mencari uang, tetapi kebutuhan untuk merefleksikan diri dan berlibur juga dibutuhkan (Pariwisata et al., 2016; Risman et al., 2016). Wisata sangat digemari oleh seluruh kalangan masyarakat, tua, muda, kaya dan miskin. 
Kesadaran masyarakat akan pentingnya desawisata sangat dibutuhkan. Dan untuk menumbuhkan kesadaran masyarakat dan Pokdarwis dapat dilakukan melalui kegiatan Program Kemitraan Masyarakat, seperti yang telah dilaskanakan di Desa Sitiluhur Kecamatan Gembong Kabupaten Pati oleh DA, Fahmi et al (Fahmi et al., 2018) Pariwisata juga memiliki kontribusi yang nyata dalam meningkatkan kesejahteraan masyarakat (Risman et al., 2016). Salah satu bentuk pariwisata yang sedang dikembangkan oleh Pemerintah adalah desawisata.

Desawisata adalah salah satu program pemerintah pusat yang bertujuan untuk menggerakkan roda perekonomian di daerah pedesaan. Salah satu lokasi desawisata adalah Desa Galengdowo, kecamatan Wonosalam Kabupaten Jombang. Desa Galengdowo memiliki potensi yang besar di bidang wisata, karena desa ini terletak di daerah pegunungan di Kabupaten Jombang. Desa Galengdowo ini berada di wilayah sebelah Selatan dari kecamatan Wonosalam. Desa Galengdowo berbatasan dengan desa Jarak dan Wonomerto di sebelah Utara, dengan Kabupaten Mojokerto dan Kabupaten Malang di sebelah Timur, dengan Desa Medowo, Kecamatan Kandangan Kabupaten Kediri di sebelah Selatan dan dengan desa Karangan Kecamatan Bareng di sebelah Barat.

Desa Galengdowo memiliki luas 389,785 Ha. Jumlah penduduk desa Galengdowo pada tahun 2018 sebanyak 3.069 jiwa, yang terdiri dari laki-laki sebanyak 1.524 jiwa dan perempuan sebanyak 1.545 jiwa. Ada sebagian kecil penduduk desa Galengdowo yang beragama hindu, sehingga setiap perayaan hari raya agama Hindu, juga dapat mendatangkan wisatawan walaupun masih wisatawan lokal. Sebagian besar penduduk desa Galengdowo berprofesi sebagai wiraswasta, yaitu sebanyak 1.013 orang dan sebagai petani sebanyak 219 orang pada tahun 2018 (Badan Pusat Statistik Kabupaten Jombang, 2019).

Desa ini memiliki wilayah yang dapat dikembangkan untuk menjadi desa wisata, karena di desa ini ada lahan-lahan yang dapat dijadikan obyek wisata, misalnya ternak sapi perah, Bumi Perkemahan, Air terjun, Grojokan Kalisat, Gua Jepang, dan Air Terjun Jurang Singo, wisata petik buah sala, wahan bermain air di kolam renang. Selain potensi wisata tersebut, desa Galengdowo juga memiliki BUMDesa (Badan Usaha Milik Desa) yang diberi nama BUMDesa Lohjinawi. BUMDesa ini mengelola unit usaha-unit usaha yang ada di desa Galengdowo, seperti unit usaha ternak sapi susu perah dan wisata desa yang dikelola oleh kelompok sadar wisata (POKDARWIS).

Kegiatan wisata merupakan salah satu kegiatan yang sangat digemari oleh masyarakat pada akhir abad 19, khususnya di Indonesia. Pada abad tersebut masyarakat Indonesia tidak lagi beripikir bahwa waktu yang mereka miliki hanya dihabiskan untuk bekerja dan mencari uang, tetapi kebutuhan untuk merefleksikan diri dan berlibur juga dibutuhkan (Pariwisata et al., 2016; Risman et al., 2016). Wisata sangat digemari oleh seluruh kalangan masyarakat, tua, muda, kaya dan miskin.

Kesadaran masyarakat akan pentingnya desawisata sangat dibutuhkan. Dan untuk menumbuhkan kesadaran masyarakat dan Pokdarwis dapat dilakukan melalui kegiatan Program Kemitraan Masyarakat, seperti yang telah dilaskanakan di Desa Sitiluhur Kecamatan Gembong Kabupaten Pati oleh DA, Fahmi et al (Fahmi et al., 2018) Pariwisata juga memiliki kontribusi yang nyata dalam meningkatkan kesejahteraan masyarakat (Risman et al., 2016). Salah satu bentuk pariwisata yang sedang dikembangkan oleh Pemerintah adalah desawisata.

Mitra dalam PKM ini adalah Pokdarwis yang dikelola BUMDesa Lohjinawi Desa Galengdowo Kecamatan Wonosalam Kabupaten Jombang, yang didirikan pada tahun 2016 dan sampai sekarang belum memiliki kantor, namun BUMDesa ini telah mengukir sejarah dengan prestasinya baik di tingkat kabupaten Jombang maupun di tingkat Provinsi Jawa Timur. Kepengurusan Bumdes Lohjinawi ini sebanyak 3 orang, yaitu: ketua, bagian keuangan dan bagian administrasi. Sedangkan kepengurusan Pokdarwis terdiri dari 5 (lima) orang, antara lain: ketua, wakil 
ketua, sekretaris, pengelola bumi perkemahan dan anggota.

Pengembangan desawisata di desa Galengdowo ini sudah dilakukan sejak tahun 2016. Program-program yang dilakukan oleh Mitra antara lain: simpan pinjam, desawisata, pasar desa, hippam dan unit susu. Hasil usaha Bumdes ini 20\% masuk ke pendapatan Desa dan $80 \%$ pendapatan yang diterima oleh masyarakat (Aini, 2019).

Potensi desawisata ini didukung dengan sarana jalan dan akses ke lokasi wisata yang sudah memadai, namun masih ada beberapa kekurangan fasilitas informasi bagi wisatawan yang akan berkunjung ke obyek wisata di Desa Galengdowo. Potensi desawisata ini antara lain, tampak pada gambar di bawah ini:

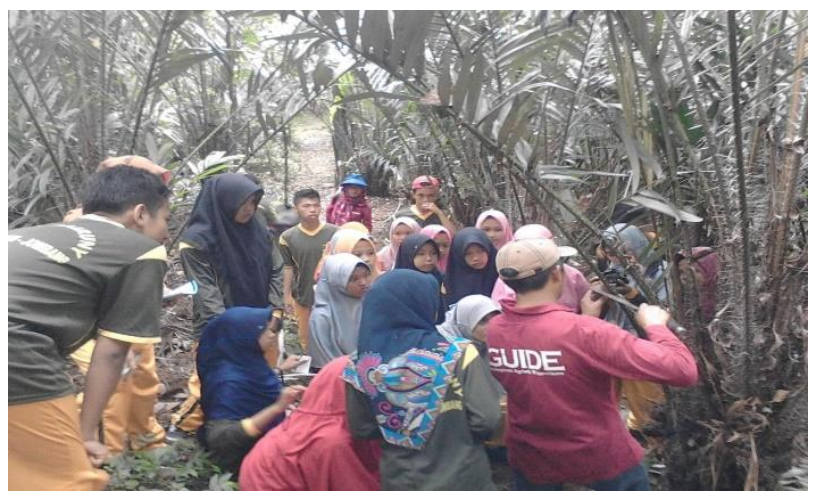

Gambar 1 Potensi Wisata Petik Buah Salah

Berbagai cara dapat dilakukan dalam pembangunan ekonomi dengan mengoptimalkan produk unggulan di suatu daerah, karena produk unggulan ini akan memberikan manfaat bagi sumber daya yang ada di daerah tersebut (Jufriyanto, 2019). Teknologi informasi dan komunikasi berkembang secara cepat dan pesat, sehingga pengelola dan masyarakat desa juga harus mengikuti perkembangan teknologi informasi dan komunikasi tersebut. Teknologi informasi dan komunikasi ini tidak hanya digunakan untuk menyebarkan informasi tetapi juga dapat digunakan untuk media promosi, jual beli, system informasi dan lain sebagainya (Fitriawan et al., 2019; Setiawan, 2020).

Permasalahan yang dihadapi Mitra (Pokdarwis Argowayang) adalah satu, masalah manajemen, yang mana masalah manajemen yang dihadapi oleh Pokdarwis berkaitan dengan manajemen kepariwisataan, karena sebagian besar pengurus masih berusia muda ( $\geq 24$ tahun) dan memiliki kesibukan masing-masing, sehingga untuk mengelola Pokdarwis secara optimal masih belum dilakukan. Masalah manajemen ini juga ditunjang dengan belum dimilikinya kantor pusat informasi wisata oleh Pokdarwis, kepengurusan Pokdarwis pernah vakum selama tahun 2019 dan telah dibentuk kembali kepengurusan yang dan telah dibentuk kembali kepengurusan yang baru yahun 2020. Dua, pemasaran atau promosi. Promosi atau pemasaran yang dilakukan oleh Pokdarwis dan Bumdes masih belum optimal, walaupun sudah menggunakan media sosial Insta Gram (IG) dan Facebook (FB), tetapi IG dan FB nya masih belum terintegrasi dengan website Desa Galengdowo.

Tujuan program ini adalah pertama, peningkatan kapasitas desawisata di masa pandemi covid-19, kedua, peningkatan promosi desawisata melalui website, ketiga, peningkatan managerial dan ketrampilan pengurus dan anggota Pokdarwis dan Bumdes di bidang kepariwisataan, dan keempat, menyediakan kelengkapan desa wisata. Urgensi dari program PKM ini adalah meningkatkan manajemen atau pengelolaan Desawisata oleh Bumdes ataupun Pokdarwis untuk meningkatkan pendapatan masyarakat. Rasionalisasi dari program ini adalah Desa Galengdowo adalah sebuah desa di Kecamatan Wonosalam Kabupaten Jombang yang memiliki potensi wisata yang besar, baik berupa wisata alam dan buatan, tetapi promosi masih belum optimal dilakukan oleh Bumdes dan Pokdarwis. Sehingga program PKM ini sangat dibutuhkan untuk meningkatkan kapasitas Desa Wisata untuk meningkatkan pendapatan masyarakat.

Solusi yang diberikan antara lain: pertama, pemasangan/pembuatan domain: http://galengdowo.id; kedua, pelatihan dan pendampingan pengisian website galengdowo.id; ketiga, pelatihan dan pendampingan manajemen kepariwisataan dan pemandu wisata, dan keempat, pembuatan dan pemasangan penunjuk arah ke lokasi obyek wisata. 


\section{METODE}

Langkah-langkah yang dilakukan dalam menyelesaikan permasalahan Mitra dalam meningkatkan kapasitas Desawisata yang dikelola oleh Pokdarwis dengan menggunakan metode pelatihan dan pendampingan terhadap Mitra yang berjumlah 1 (satu) unit usaha Pokdarwis Argowayang. Kegiatan ini dimulai dengan mengidentifikasi kebutuhan Mitra dalam mengembangkan wisata di Desa Galengdowo.

Setelah dilakukan wawancara dengan Mitra, diperoleh hasil bahwa Mitra membutuhkan pelatihan dan pendampingan manajemen pariwisata, pemandu wisata, promosi, dan penunjuk arah ke lokasi wisata. Selain itu Pokdarwis ini belum memiliki website tersendiri untuk mengenalkan atau mempromosikan destinasi dan potensi-potensi wisata di Desa Galengdowo.

\section{HASIL DAN PEMBAHASAN}

\section{Kondisi sebelum dilakukan pelatihan dan pendampingan}

Hasil wawancara menunjukkan bahwa kondisi Mitra pada saat sebelum dilakukan Program Kemitraan Masyarakat (PKM) ini pernah mati suri dan baru hidup kembali setelah dilakukan perombakan kepengurusan pada tahun 2020, sehingga Mitra tbelum dapat memberikan kontribusi kepada Pendapatan Desa dan masyarakat.

Potensi wisata di Desa Galengdowo ini sangat besar, tetapi juga masih belum mampu memberikan kontribusi kepada Pendapatan Desa dan peningkatan pendapatan masyarakat bahkan untuk penyerapan tenaga kerja. Ini disebabkan karena, manajemen organisasi yang digunakan oleh para pengurus Pokdarwis dalam mengelola Pokdarwis masih konvensional, yaitu mengelola desa wisata dengan memberikan waktu kerja yang belum optimal dan komunikasi antar pengurus dilakukan secara jarak jauh dan para pengurus kesulitan untuk menyamakan waktu untuk mengelola desa wisata ini secara optimal (hasil wawancara dengan Ketua Pokdarwis Argowayang, 10-15 Juli 2021).
Selain itu Pokdarwis Argowayang dalam mengelola desa wisata belum memiliki kantor pusat informasi wisata dan website, sehingga kesulitan dalam melakukan komunikasi, dan ini juga menyebabkan sulitnya para calon wisatawan untuk mendapatkan informasi tentang obyek wisata di Desa Galengdowo ini.

Kondisi ini juga ditunjang dengan belum terintegrasinya teknik promosi dengan potensi desa, walaupun promosi sudah dilakukan melalui IG, FB dan Tweeter, tetapi masih belum optimal, karena pengisian konten-konten di IG, FB dan Tweeter masih belum optimal dilakukan.

Fasilitas penunjang bagi calon wisatawan yang akan datang berkunjung ke lokasi wisata di Desa Galengdowo juga masih minim, misalnya belum ada penunjuk arah yang dapat memberikan informasi bagi para calon wisatawan yang akan berkunjung ke lokasi wisata, sehingga ini menyulitkan wisatawan untuk mengetahui secara langsung obyek wisata apa saja yang ada di Desa Galengdowo.

Potensi yang mendukung keberadaan desa wisata ini adalah terdapat beberapa unit usaha yang dikelola oleh Bumdesa Lohjinawi (misalnya, usaha premen dan yogart dari susu sapi yang dihasilkan oleh peternak sapi di Desa Galengdowo, usaha aneka macam jamu, kripik salak dan sebagainya). Unit Usaha Mikro dan Kecil (UMK) ini dalam membuat produk-produknya menggunakan bahan baku yang berasal dari desa Galengdowo. Dan produk-produk yang dihasilkan ini dapat digunakan untuk mendukung keberadaan desawisata. Untuk mempromosikan desa wisata tidak hanya dilakukan dengan menawarkan obyek wisata saja tetapi juga produk-produk unggulan daerah dapat juga ditawarkan untuk mendukung desa wisata .

\section{Kondisi setelah dilakukan pelatihan dan pendampingan}

Program Kemitraan Masyarakat ini dilaksanakan secara offline, ini yang diinginkan oleh Mitra. Mitra memberikan argumentasi, jika pelatihan dilakukan secara online, hasilnya kurang 
memuaskan, karena kurang fokus dalam mengikuti kegiatan pelatihan secara online.

Pembuatan website atau domain http://gelengdowo.id, yang dikhususkan untuk pengenalan dan pengembangan desa wisata. Website ini dibuat dan ditautkan oleh Tim PKM, dengan tujuan untuk mengenalkan dan mengembangkan desa wisata di Desa Galengdowo. Selain itu tujuannya adalah agar Desa Galengdowo memiliki informasi khusus tentang lokasi, obyek dan potensi wisata serta produk unggulan yang layak dijual atau ditawarkan kepada calon wisatawan. Gambar domain atau website galengdowo.id tampak pada Gambar 2 berikut:

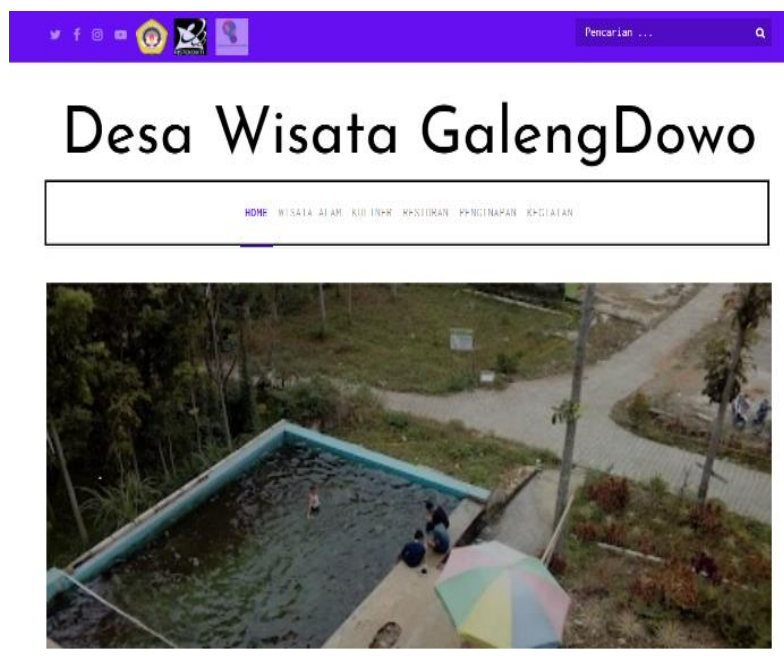

Gambar 2 Website galengdowo.id

Selain membuatkan domain galengdowo.id, program kemitraan ini juga memberikan pelatihan dan pendampingan dalam mengoperasikan dan mengisi fitur-fitur di website galengdowo.id, manajemen kepariwisataan dan pemandu wisata. Pelatihan dan pendampingan ini diikuti oleh 10 (sepuluh) orang yang terdiri dari pengurus dan anggota Bumdes Lohjinawi dan Pokdarwis Argowayang.

Hasil pelatihan dan pendampingan menunjukkan bahwa: pertama, pelatihan dan pendampingan mengoperasikan website dan mengisikan data ke dalam fitur-fitur yang ada di website dengan tujuan agar para peserta pelatihan memahami bagaimana cara untuk mengisikan data- data yang diperlukan untuk mengembangkan desa wisata ke dalam website galengdowo.id. Setelah dilakukan pelatihan dan pendampingan peserta dipantau oleh Tim PKM dengan melihat website galengdowo.id apakah sudah ada perubahan kontennya atau belum, dan jika belum, maka akan dilakukan komunikasi dengan pengurus Pokdarwis dan Bumdes. Kedua, setelah diberikan pelatihan manajemen kepariwisataan, Mitra meningkat pengetahuan dan pemahaman dalam mengelola wisata, khususnya berkaitan dengan peran masingmasing pengurus dalam Bumdes Lohjinawi dan Pokdarwis Argowayang, ini ditunjukkan dari isian google form yang telah diberikan kepada para peserta). Peningkatannya sebesar kurang lebihnya 50 persen dibandingkan sebelum mendapatkan pelatihan dan pendampingan. Ketiga, setelah diberikan pelatihan pemandu wisata, Mitra ada keinginan untuk mengikuti pendidikan dan pelatihan dan sertifikasi sebagai pemandu wisata (tour guide), bahkan Direktur Bumdes Lohjinawi menyampaikan bahwa untuk pembiayaan akan dapat ditanggung oleh Bumdes. Pengetahuan dan pemahaman peserta mengalami peningkatan kurang lebihnya 70 persen. Ini menunjukkan bahwa pelatihan dan pendampingan ini sangat diminati dan dibutuhkan oleh para peserta. Keempat, setelah diberikan pelatihan dan pendampingan membuat dan mengoperasikan website, pengetahuan dan ketrampilan peserta meningkat, hal ini dibuktikan dengan keinginan peserta untuk mengoperasikan website melalui android yang dimiliki. Hasil dari pelatihan manajemen kepariwisataan dan pemandu wisata ini tampak pada Gambar berikut:

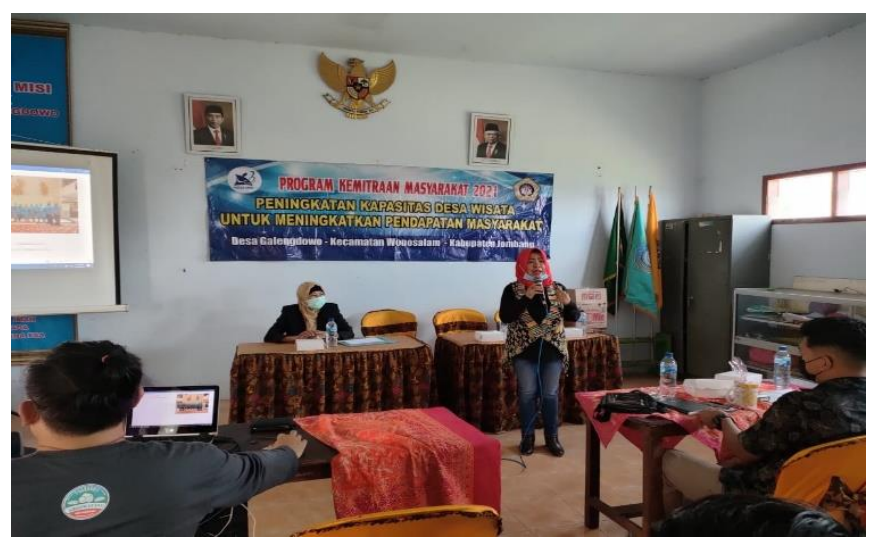




\section{Gambar 3 Pelatihan dan Pendampingan Majamenen kepariwisataan \&Pemandu Wisata}

Hasil wawancara dengan peserta menunjukkan bahwa sebelum mengikuti pelatihan dan pendampingan ini, peserta sebagian belum tahu tentang teknik membuat dan mengoperasikan website, database, manajemen kepariwisataan dan pemandu wisata. Tim menawarkan beberapa solusi untuk membantu Mitra, yaitu: satu, pelatihan dan pendampingan kembali. Dua, memberikan tutorial dalam mengoperasikan website melalui youtube. Video tutorial ini dapat diunduh di link: https://www.youtube.com/channel/UCC2D_tiNCY9 -NnJX-aDRlkQ.

Dampak dari kegiatan PKM bagi Mitra sasaran adalah positif, karena walaupun kegiatan PKM ini dilaksanakan pada masa pemberlakuan Pemberlakuan Pembatasan Kegiatan Masyarakat (PPKM), Mitra sangat tanggap dalam mengikuti dan mendukung (memfasilitasi) kegiatan PKM ini. Dampak dari kegiatan PKM ini, antara lain: satu, Mitra akan segera melakukan koordinasi dengan pengurus dan anggota untuk melakukan pengisian data base wisata di website galengdowo.id; dua, Mitra akan segera memasang penunjuk arah yang sudah diberikan oleh TIM PKM, tiga, Mitra akan segera membuat desain poster untuk mempromosikan potensi wisata melalui website.

Hambatan atau kendala yang dihadapi oleh Mitra akan segera dapat teratasi jika para pengurus dan anggota Pokdarwis dan Bumdes memberikan waktunya untuk serius mengelola Pokdarwis. Setelah mempelajari tutorial yang diberikan oleh Tim, Mitra lebih memahami teknik atau cara untuk mengisi dan mengoperasikan website. Selain itu, kecanggihan informasi melalui internet sangat dibutuhkan oleh pebisnis atau pelaku usaha dalam mengembangkan usahanya (Werdani et al., 2020). Selain itu, data jumlah hotel atau penginapan, jumlah kuliner, jumleh obyek wisata, jumlah perdagangan souvenir ini juga akan mempengaruhi jumlah wisatawan yang akan berkunjung ke obyek wisata (Dwiningwarni et al., 2021). Program pemberdayaan masyarakat sangat perlu dilakukan melalui berbagai cara, salah satunya adalah melalui peningkatan skala usaha UMK yang ada di desa (Dwiningwarni et al., 2020).

Dari kegiatan PKM ini belum dapat dilihat secara langsung dampaknya kepada peningkatan pendapatan Pokdarwis ataupun pendapatan masyarakat di desa Galengdowo, karena masih dalam kondisi pandemic covid-19 dan diberlakukannya PPKM level 1-4. Kondisi inilah yang menyebabkan masih belum dibukanya obyek wisata di Desa Galengdowo Kecamatan Wonosalam Kabupaten Jombang, sehingga pendapatan Bumdes ataupun Pokdarwis dari unit usaha desa wisata masih belum ada pemasukan.

Kegiatan PKM yang telah dilaksanakan ini dapat meningkatkan kompetensi Pokdarwis di bidang pemanudan wisata dan masyarakat desa dapat melakukan pemotretan potensi daerahnya untuk menjadi tujuan wisata dengan cara mengkemas desa menjadi desa wisata (Umam et al., 2020). Permintaan dan harapan yang meningkat mengenai infrastruktur dan fasilitas di destinasi yang diperiksa dapat dikaitkan dengan posisi destinasi di TALC (Mandic et al., 2018). Penduduk pedesaan yang terikat dengan wilayah tempat tinggal mereka menyadari manfaat yang dapat dibawa oleh pariwisata dan juga bahwa keterikatan masyarakat dapat berdampak positif pada persepsi penduduk (Bajrami et al., 2020).

\section{KESIMPULAN}

Program Kemitraan Masyarakat ini dapat ditarik simpulan sebagai berikut: Pertama, setelah dilakukan pelatihan dan pendampingan website dan data base, Mitra ada kesanggupan untuk mengisi data base wisata yang ada di Desa Galengdowo. Kedua, setelah pelatihan dan pendampingan manajemen kepariwisataan dan pemandu wisata, Mitra ada keinginan untuk memperbaiki pengelolaan unit usaha desa wisata, khususnya yang berkaitan dengan job description untuk masingmasing pengurus Pokdarwis. Dan Mitra juga ada keinginan untuk mengikuti pendidikan dan pelatihan sebagai pemandu wisata (tour guide) yang bersetifikasi. Ketiga, tersedianya kelengkapan 
penunjuk arah ke lokasi wisata, sangat membantu kepada para calon wisatawan untuk berkunjung ke lokasi obyek wisata di Desa Galengdowo.Kesimpulan berisi rangkuman hasil kegiatan pengabdian kepada masyarakat dan implikasi dari kegiatan yang dilaksanakan.

\section{UCAPAN TERIMAKASIH}

Tim mengucapkan terima kasih kepada Direktorat Riset dan Pengabdian Masyarakat Deputi Bidang Penguatan Riset dan Pengembangan Kementerian Riset dan teknologi/Badan Riset dan Inovasi Nasional yang telah memberikan pendanaan hibah Program Kemitran Masyarakat tahun 2021. Ucapan terima kasih juga kami sampaikan kepada Bapak Rektor Universitas Wijaya Putra, Bapak Dr. H. Budi Endarto, SH.,M.Hum dan Bapak Ketua LPPM Universitas Wijaya Putra, yang telah memberikan dukungan dan kesempatan kepada Tim untuk melakukan kegiatan PKM ini.

\section{REFERENSI}

Aini, S. N. (2019). Pengembangan Potensi Desa Melalui Badan Usaha Milik Desa ( BUM Desa ) Lohjinawi Dalam Meningkatkan Pendapatan Asli Desa Galengdowo Kecamatan Wonosalam Kabupaten Jombang SKRIPSI Untuk Memenuhi Sebagai Syarat Memperoleh Gelar Sarjana Program Studi Akuntansi [SITE PGRI Dewantara Jombang]. http://repository.stiedewantara.ac.id/1358/1/1. COVER.pdf

Badan Pusat Statistik Kabupaten Jombang. (2019). Kecamatan Wonosalam Dalam Angka 2019.

Bajrami, D. D., Radosavac, A., Cimbaljević, M., Tretiakova, T. N., \& Syromiatnikova, Y. A. (2020). Determinants of residents' support for sustainable tourism development: Implications for rural communities. Sustainability (Switzerland), 12(22). https://doi.org/10.3390/su12229438

Dwiningwarni, S. S., Aristyanto, E., Riswati, F., \& , M. (2020). Ppm Olahan Buah Naga Di Desa Baron Kecamatan Baron Nganjuk. Prosiding
Konferensi Nasional Pengabdian Kepada Masyarakat Dan Corporate Social Responsibility (PKM-CSR), 3, 984-989. https://doi.org/10.37695/pkmcsr.v3i0.764

Dwiningwarni, S. S., Mardiana, F., \& Wahyuningdyah, E. T. (2021). Tourism Village and Impact on Labor Absorption in Jombang Regency. Proceedings of the 2nd International Conference on Business and Management of Technology (ICONBMT 2020), 175(6), 208-218. https://doi.org/10.2991/aebmr.k.210510.035

Fahmi, D. A., Wibisana, M. I. N., Ginting, R., Pratama, D. S., \& Hidayat, R. (2018). Program Kemitraan Masyarakat (PKM) Pengembangan Desa Wisata di Desa Sitiluhur Kecamatan Gembong Kabupaten Pati. Journal of Dedicators Community, 2(1), 39-43. https://doi.org/10.34001/jdc.v2i1.683

Fitriawan, H., Murdika, U., \& Yudamson, A. (2019). PENGEMBANGAN WEBSITE DESA PEKON KILUAN NEGERI MENUJU KAWASAN WISATA BERBASIS TIK. Sakai Sambayan Jurnal Pengabdian Kepada Masyarakat, $3(3)$. https://doi.org/10.23960/jss.v3i3.162

Jufriyanto, M. (2019). Pengembangan Produk Unggulan Sebagai Potensi Peningkatan Ekonomi Masyarakat Desa di Kecamatan Modung Bangkalan. Jurnal Ilmiah Pangabdhi, $5(1)$. https://doi.org/10.21107/pangabdhi.v5i1.5162

Mandic, A., Mrnjavac, Ž., \& Kordic, L. (2018). Tourism infrastructure, recreational facilities and tourism development. Tourism and Hospitality Management, 24(1). https://doi.org/10.20867/thm.24.1.12

Pariwisata, K., Sudiarta, I. N., \& Wayan, I. (2016). Dampak Pariwisata terhadap Kemiskinan di Kawasan Pariwisata di Bali. Jurnal Kajian Bali, 6(2), 209-228.

Risman, A., Wibhawa, B., \& Fedryasyah, M. (2016). Kontribusi Pariwisata Dalam Peningkatan Kesejahteraan. Prosiding 
Penelitian Dan Pengabdian Kepada Masyarakat, 3(1), 1-154.

Setiawan, A. H. (2020). Pelatihan Pengembangan Sistem Informasi Dan Promosi Rintisan Desa Wisata Kembang Sari Kabupaten Temanggung. Abdi Seni, 10(1). https://doi.org/10.33153/abdiseni.v10i1.3036

Umam, C., Pangesti, F. S. P., \& Yuslistyari, E. I. (2020). Pemberdayaan Pokdarwis Tazgk Dalam Pengembangan Desa Wisata Di Kaduengang. Sawala: Jurnal Pengabdian Masyarakat Pembangunan Sosial, Desa Dan Masyarakat, $\quad 1(1), \quad 17$. https://doi.org/10.24198/sawala.v1i1.25838

Werdani, R. E., Kurniawati, N. I., Sukoco, J. B., Windriya, A., \& Iskandar, D. (2020). Pelatihan Pemasaran Produk Homemade Melalui Sosial Media. JPPM (Jurnal Pengabdian Dan Pemberdayaan Masyarakat), 4(1), 1. https://doi.org/10.30595/jppm.v4i1.4655 